IZA DP No. 3786

Trade as a Wage Disciplining Device

Damiaan Persyn

October 2008 


\title{
Trade as a Wage Disciplining Device
}

\author{
Damiaan Persyn \\ LICOS, Catholic University of Leuven \\ and IZA
}

\section{Discussion Paper No. 3786 \\ October 2008}

\author{
IZA \\ P.O. Box 7240 \\ 53072 Bonn \\ Germany \\ Phone: +49-228-3894-0 \\ Fax: +49-228-3894-180 \\ E-mail: iza@iza.org
}

\begin{abstract}
Any opinions expressed here are those of the author(s) and not those of IZA. Research published in this series may include views on policy, but the institute itself takes no institutional policy positions.

The Institute for the Study of Labor (IZA) in Bonn is a local and virtual international research center and a place of communication between science, politics and business. IZA is an independent nonprofit organization supported by Deutsche Post World Net. The center is associated with the University of Bonn and offers a stimulating research environment through its international network, workshops and conferences, data service, project support, research visits and doctoral program. IZA engages in (i) original and internationally competitive research in all fields of labor economics, (ii) development of policy concepts, and (iii) dissemination of research results and concepts to the interested public.
\end{abstract}

IZA Discussion Papers often represent preliminary work and are circulated to encourage discussion. Citation of such a paper should account for its provisional character. A revised version may be available directly from the author. 
IZA Discussion Paper No. 3786

October 2008

\section{ABSTRACT}

\section{Trade as a Wage Disciplining Device ${ }^{*}$}

We estimate how trade openness affects the relationship between wages, labour productivity and foreign wages using sector-level time series for several EU member states. In some countries wages became less responsive to foreign wages as trade costs declined. We show this counter-intuitive result is as expected when wages are set by a monopoly union with a preference for wages relative to employment. Trade liberalisation then leads to more wage discipline by forcing unions to set wages more in line with labour productivity. Foreign wages simultaneously become less relevant. Our results call to rethink how trade liberalisation is affecting unionized labour markets, and offer a possible explanation for the mixed evidence found by some tests for international factor price convergence.

JEL Classification: J50, J31, F16

Keywords: unions, globalisation, economic geography, factor price equalisation

Corresponding author:

Damiaan Persyn

LICOS Centre for Institutions and Economic Performance

K.U.Leuven

Debériotstraat 34

3000 Leuven

Belgium

E-mail: damiaan.persyn@econ.kuleuven.be

\footnotetext{
* I wish to thank Joep Konings, Maarten Goos, Rodrigo Paillacar, Daniel Mirza, Italo Colantone, Stijn Vanormelingen, Ziga Zarnic, John Hutchinson, Veerle Slootmaekers, Ilke Van Beveren, Marton Csillag and LICOS and CEPII seminar participants for helpful comments which have greatly improved the paper.
} 


\section{Introduction}

The European Union has become increasingly economically integrated over the last decades. Vast improvements in transport infrastructure, streamlining of legislation and reforms such as the creation of a single market and currency have greatly facilitated trading with other member states. Firms have become more footloose and many firms have set up or relocated some production and sales plants abroad. The integration process has manifested itself in a significant increase in intra-EU trade and FDI relative to GDP.

The process of trade liberalisation has been welcomed by many, but has equally been perceived as increasing the exposure of local workers to foreign competition. As such economic integration would pose a threat to the labour market position of workers, both in terms of wages and employment opportunities. The economic literature has analysed the possible effects of trade liberalisation on employment and wages in a wide variety of settings. It is not our aim to summarise this literature here as excellent surveys can be found in, for example, Hoekman and Winters (2005) and Feenstra and Hanson (2004). Our paper builds on two strands of this literature which we want to single out.

Many studies test for factor price equalisation or convergence, one of the key predictions of the classic Heckscher-Ohlin model of international trade (see Leamer, 1995, for a discussion). For the EU, Tovias (1982), Gremmen (1985) and Webber and White (2003) find mixed results on whether European economic integration has contributed to wage convergence. Burgman and Geppert (1993) test whether wages in different EU countries are co-integrated. Our approach is related to the factor price convergence literature in that we develop a measure of trade integration and investigate whether trade integration has strengthened the link between wages in different countries. The dependency of wages on the foreign wage level does not have to be driven by market forces alone, however. In Belgium, for example, the government responded to increasing international competition and the deteriorating relative cost competitiveness of the country by setting a maximum yearly wage increase for sectoral wage negotiations as an explicit function of the wage evolution in neighbouring countries. In a similar vein the monopoly union in the small theoretical model we set up rationally adjust its wage demands in function of the foreign wage level in order to preserve employment. More wage discipline abroad then leads to more local wage discipline and trade integration is intuitively expected to strengthen the international interdependency of wages.

In a different branch of literature with early contributions from for example Grossman (1987) and Revenga (1992) the effect of import competition on wages and employment is analysed. Market rigidities and unionisation play an important role in the analysis of the effects of trade on labour markets. 
Macpherson and Stewart (1990) estimated the effect of import penetration on the difference between union and non-union wages. Boulhol et al. (2007) consider the effect of import penetration on union bargaining power. Abowd and Lemieux (1990) consider employment and wage effects of imports and exports on unionised labour markets. Fontagné and Mirza (2007) look at export market shares. Unlike most of these studies we aim to investigate the overall effect of trade openness on employment and wages without differentiating between imports and exports. Our approach is more related to Mezzetti and Dinopoulos (1991) and related papers, where trade liberalisation limits the scope for union wage demands by improving the relocation possibilities of firms. In this context trade openness is expected to induce wage discipline by decreasing the union wage gap, bringing wages more in line with labour productivity.

In section 2 we set up a simple model to analyse these two disciplinary effects of trade on a unionised labour market. We start by deriving the optimal wage demand of a monopoly union operating on the sector level while facing internationally mobile firms. Trade liberalisation makes firms more footloose, which increases the cost of raising wages above the value of the marginal product of labour in terms of lost employment. Lower trade costs then imply lower wages. Wages become more sensitive to either local labour productivity or the foreign wage level as trade costs decline, depending on the union preference for wages relative to employment. Using minimal assumptions we derive following predictions (1) if unions prefer wages over employment, wages are unit elastic with respect to foreign wages and inelastic with respect to local labour productivity in autarky; (2) if trade is liberalised the sensitivity of wages with respect to labour productivity increases and the sensitivity to foreign wages decreases; (3) if unions are employment oriented, the opposite holds.

These predictions are shown to hold empirically in section 3, using the extensive EUKLEMS and CEPII Trade and Production datasets. We proceed in three steps. Firstly, we calculate country-sector specific intra-EU trade costs using bilateral sector-level trade data. The results confirm that the last two decades of the previous century were characterised by a significant decline in intra-EU trade costs. Secondly, we show that the employment cost of increasing wages has been increased by trade liberalisation. Thirdly, we show that, on average, trade liberalisation lead to more wage discipline in the form of wages moving more in line with labour productivity, and not -after controlling for labour productivity- with an increased responsiveness to foreign wages.

Our results suggest that on average unions give more weight to wages relative to employment in the EU. Large differences between countries and sectors exist, however, indicating that unions in countries such as Germany care more about employment compared to their Southern-European counterparts. Measuring the wage orientation of unions by the existence of a statutory minimum wage and the variability of wages over the business-cycle relative to employ- 
ment, we confirm that in countries with wage-oriented unions trade liberalisation leads to more wage discipline by bringing wages more in line with labour productivity, and not through strengthening the link with the foreign wage level. In countries with employment oriented unions the reverse holds.

These results call to rethink the labour market effects of trade liberalisation. They also offer an explanation for the mixed results of tests for factor price equalisation or factor price convergence which are based on directly investigating the relationship between wages in different countries (as in, for example, Burgman and Geppert, 1993; Jung and Doroodian, 2000; Andersen et al., 2000; Berger and Westermann, 2001), and raise doubts about the validity of such tests. Wages might converge internationally but simultaneously become less interdependent.

\section{Union wage demands with internationally mobile firms}

\subsection{Homogeneous union preferences}

Consider a monopoly union acting on the sector level, unilaterally setting wages $h$ as to maximise a homogeneous utility function $U(h, f, a)$, where $f$ is the level of foreign wages and $a$ is the wage level in some large non-unionised sector of the economy, equal to the value of the marginal product of labour. Examples of such functions $U$ are given later on.

The optimal union wage demand is characterised by

$$
F(h, f, a)=\frac{\partial U}{\partial h}=0 .
$$

The implicit function theorem can be used to analyse how the union wage demand changes in function of model parameters. Expressing changes in the optimal union wage demand in function of $f$ and $a$ as elasticities, we obtain

$$
\epsilon_{f}^{h}=\frac{\mathrm{d} h}{\mathrm{~d} f} \frac{f}{h}=-\left(\frac{\partial F}{\partial f} / \frac{\partial F}{\partial h}\right) \frac{f}{h} \quad \text { and } \quad \epsilon_{a}^{h}=\frac{\mathrm{d} h}{\mathrm{~d} a} \frac{a}{h}=-\left(\frac{\partial F}{\partial a} / \frac{\partial F}{\partial h}\right) \frac{a}{h} .
$$

If $U$ is homogeneous of degree $r, F$ must be homogeneous of degree $r-1$. By Euler's theorem this implies

$$
\frac{\partial F}{\partial h} h+\frac{\partial F}{\partial f} f+\frac{\partial F}{\partial a} a=(r-1) F=0 .
$$


Dividing by $\frac{\partial F}{\partial h} h$ and using the above definitions then shows

$$
\epsilon_{f}^{h}+\epsilon_{a}^{h}=1
$$

If these elasticities depend on some model parameter $\phi$, it must hold that

$$
\frac{\mathrm{d} \epsilon_{f}^{h}}{\mathrm{~d} \phi}+\frac{\mathrm{d} \epsilon_{a}^{h}}{\mathrm{~d} \phi}=0 \quad \text { or } \quad \frac{\mathrm{d} \epsilon_{f}^{h}}{\mathrm{~d} \phi}=-\frac{\mathrm{d} \epsilon_{a}^{h}}{\mathrm{~d} \phi} .
$$

The effect of any model parameter on $\epsilon_{f}^{h}$ and $\epsilon_{a}^{h}$ must therefore be opposite. Following proposition summarises these results.

Proposition 1 If union preferences are homogeneous in home wages $h$, foreign wages $f$ and the alternative wage a, the elasticities of union wages with respect to $f$ and a must sum to one. As a result the effect of model parameters on these elasticities must be opposite.

To derive more properties of the union wage we quantify union utility $U$. Assume the union operates on the sector level and has a preference for both aggregate employment $n L$ (with $n$ the number of active firms in the sector and $L$ the labour demand of a typical firm), and for the difference between wages and the wage in a non-unionised sector of the economy $(h-a)$. Workers are assumed to be internationally immobile and gauge wage demands against the alternative of employment in the local non-unionised sector. The union maximises a weighted product of aggregate employment and the wage difference:

$$
U=n(h, f) L(h)(h-a)^{\gamma},
$$

where $\gamma>0$ is the weight of the wage difference relative to employment. ${ }^{2}$ If $\gamma>1$ unions are wage oriented. This is a standard specification for union utility (see for example Layard et al., 2005), apart from the fact aggregate labour demand depends on the foreign wage level and trade costs through their effect on the number of firms $n$ in a country.

When the union demands higher wages, firms hire less labour and some firms relocate (decreasing $n$, the number of active firms in the sector). ${ }^{3}$ For labour demand we assume $L(h)=h^{-\epsilon}$, where $-\epsilon<0$ is the elasticity of labour demand. As for the number $n$ of active firms we impose that only relative wages $h / f$ matter to firm location. It can easily be verified that under these assumptions following proposition holds.

2 The empirical literature suggests $\gamma<1$, given the regularity that wages vary less than employment over time. Pehkonen (1990) gives an estimate of $\gamma \approx 0.2$, with employment entering linearly in union preferences as in our specification.

3 Note that we could assume capital rather than physical firms relocate, as in Martin and Rogers (1995). 
Proposition 2 Union utility functions of the form $U=n(h / f) h^{-\epsilon}(h-a)^{\gamma}$ are homogeneous of degree $\gamma-\epsilon$ in $h, f$ and $a$.

A wide variety of models from the economic geography literature could serve to describe the number of firms $n$ which locate in a country. This typically requires assumptions on consumer preferences, firm pricing behaviour, etc. Not all of these models will be characterised by $n$ depending only on the ratio of wages. Allowing for international wage differences in the footloose capital model of Martin and Rogers (1995) results in a number of firms given by

$$
n=\frac{h}{f} \frac{m\left(1-\phi^{2}\right)+\phi^{2}-\phi h / f}{(\phi-h / f)(\phi h / f-1)}
$$

where $m$ is the appropriately normalised market size of the country and $\phi$ is a measure of the freeness of trade which is decreasing in transport costs. Only relative wages matter to firm location, union utility therefore is homogeneous of degree $\gamma-\epsilon$ and the properties of union wages derived above therefore hold for this specification of $n$.

As the derivations become lengthy and un-insightful using this theoretically underpinned specification for $n$, we use following ad-hoc definition for the remainder of this paper

$$
n(h, f, m, \phi)=m-\phi\left(\frac{h}{f}-1\right) .
$$

In autarky $(\phi=0)$, or in the absence of an international wage differential $(h=f)$ the number of firms equals the (appropriately normalised) market size $m$. As trade becomes freer (a higher $\phi$ ), the international wage differential becomes more relevant to firm location. The results obtained from this model are qualitatively similar as those obtained using the extended model of Martin and Rogers (1995).

2.2 The effect of labour productivity, foreign wages and trade costs on union wage demands

Given the union preferences from equation (2) the first order condition for the optimal union wage demand can be written as

$$
h=a+a \frac{\gamma}{-\epsilon_{h}^{n}-\epsilon_{h}^{L}-\gamma},
$$

where we write $\epsilon_{h}^{n}$ for the elasticity of $n$ with respect to wages $h$, and $\epsilon_{h}^{L}$ is the wage elasticity of firm level labour demand. 
Assuming $L(h)=h^{-1}$ and using the simple specification for firm location from equation (3), exact expressions for $\epsilon_{f}^{h}, \epsilon_{a}^{h}, \mathrm{~d} \epsilon_{f}^{h} / \mathrm{d} \phi$ and $\mathrm{d} \epsilon_{a}^{h} / \mathrm{d} \phi$ can be derived. The optimal union wage demand is

$$
h=\frac{(\gamma-1)(\phi+m) f+\sqrt{(\gamma-1)^{2}(\phi+m)^{2} f^{2}+4 \phi \gamma(\phi+m) a f}}{2 \phi \gamma} .
$$

Union wage demands are increasing in the alternative wage $a$, the home market size $m$, foreign wages $f$ and the weight of wages in union preferences $\gamma$. Wage demands decrease as trade becomes freer as measured by $\phi$.

Taking the derivative of $h$ with respect to the foreign wage level $f$ and rearranging shows

$$
\epsilon_{f}^{h}=\frac{1}{2}+\frac{\sqrt{f(\phi+m)}(\gamma-1)}{2 \sqrt{f(\phi+m)(\gamma-1)^{2}+4 \phi \gamma a}} .
$$

If unions care just as much about wages and employment $(\gamma=1)$ and trade costs are not prohibitively high $(\phi>0)$ we have $\epsilon_{f}^{h}=\epsilon_{a}^{h}=1 / 2$. Union wage demands then are equally sensitive to changes in foreign wages and changes in the alternative wage. If unions are biased toward wages $(\gamma>1)$, we have $\epsilon_{f}^{h}>1 / 2$ and $\epsilon_{a}^{h}<1 / 2$, and vice-versa for $\gamma<1$. The results for $\epsilon_{a}^{h}$ follow directly from equation (1) or proposition 1.

Our main interest lies with the question how the sensitivity of the optimal union wage demand with respect to its determinants changes in function of trade costs. The effect of $\phi$ on $\epsilon_{f}^{h}$ is given by

$$
\frac{\mathrm{d} \epsilon_{f}^{h}}{\mathrm{~d} \phi}=\frac{(1-\gamma) \gamma m \sqrt{f} a}{\sqrt{\phi+m}\left((\phi+m) f(\gamma-1)^{2}+4 \phi \gamma a\right)^{3 / 2}} .
$$

As the expression is positive for $\gamma>1$ and negative for $\gamma<1$, freer trade decreases or increases the sensitivity of union wages to foreign wages depending on whether unions are wage or employment oriented, respectively.

In the limiting case of complete autarky $(\phi=0), \epsilon_{f}^{h}$ simplifies to

$$
\left.\epsilon_{f}^{h}\right|_{\phi=0}=\frac{1}{2}+\frac{\gamma-1}{2 \sqrt{(\gamma-1)^{2}}}= \begin{cases}1 & \text { if } \gamma>1 \\ 0 & \text { if } \gamma<0\end{cases}
$$

In autarky union wages are unit elastic with respect to foreign wages in the case where unions prefer wages over employment, and are completely insensitive to the foreign wage level in the case unions are employment oriented.

Figure 1 illustrates the results on the effect of $\phi$ on wages (solid line), the sensitivity to foreign wage changes as expressed by $\epsilon_{f}^{h}$ (dashed line) and the 
sensitivity of wages with respect to local labour productivity $\epsilon_{a}^{h}$ (dotted line). The left panel shows the case of an employment oriented union $(\gamma=0.8)$, the
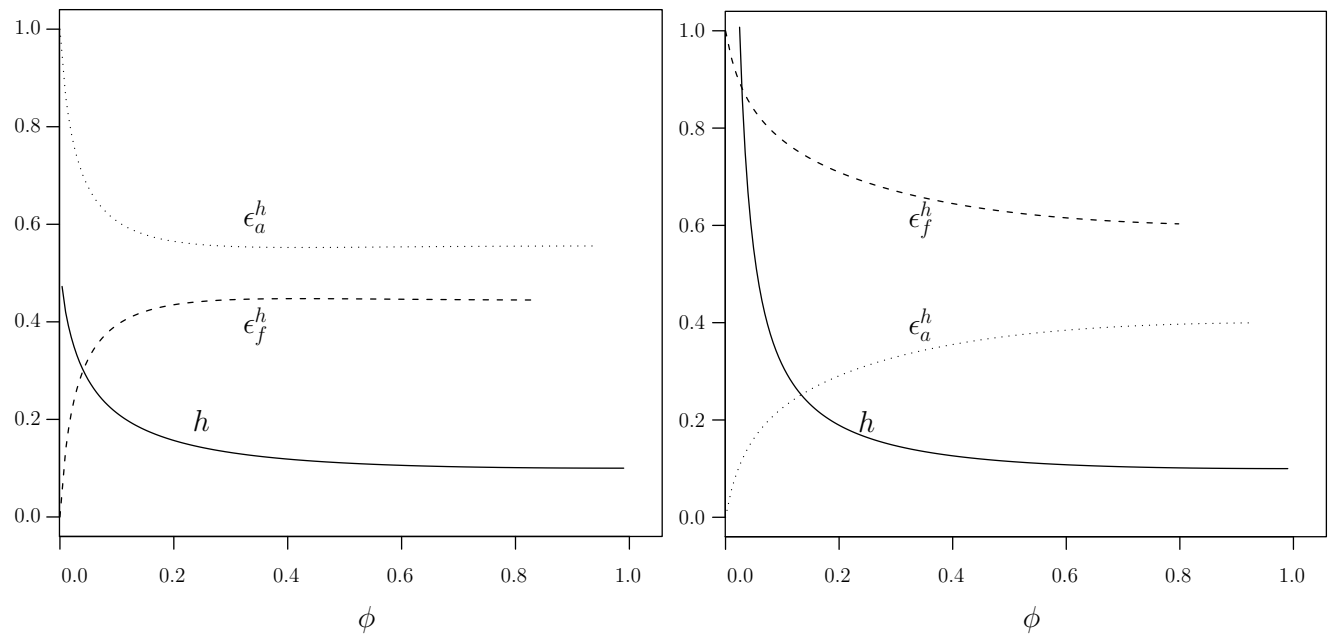

Fig. 1. The effect of $\phi$ on wages (solid line), the sensitivity of wages to productivity (dotted line) and the sensitivity to foreign wages (dashed line). In the left panel unions weigh employment more than wages and vice versa in the right panel.

right panel the case of strong union preferences for wages $(\gamma=1.5)$. As the case $\gamma=0.8$ is close to an equal weight of wages and employment $(\gamma=1)$, both elasticities are close to $1 / 2$ unless trade costs are high (see equation (6)).

It might appear counter-intuitive that there exist configurations in which wages are more sensitive to the foreign wage level in a more closed economy. Some intuition on the effect of trade costs on the sensitivity of union wage demands with respect to foreign wages and productivity can be gained by considering the structure of the union utility function and first order condition in the extreme case of an economy close to autarky.

First consider the case of a wage oriented union $(\gamma>1)$. In this case the term $-\epsilon_{h}^{L}-\gamma$ in the denominator of the expression for the union wage demand in equation (4) is small. If transport costs are high, the number of firms in a country is relatively insensitive to relative wages $\left(-\epsilon_{h}^{n}\right.$ is small, see equation (3)) and the union increases its wage demands far above the outside-option wage $a$. Wages become less related to the alternative wage and, by proposition 1 , they become more sensitive to foreign wages.

The properties can also be understood from the structure of union utility $U=n(h, f) L(h)(h-a)^{\gamma}$, and the assumed firm behaviour. If unions prefer wages to employment, high union wage demands will induce firms to relocate and local firms will reduce their workforce, leading to a low level of aggregate labour demand $n(h, f) L(h)$, relative to $(h-a)^{\gamma}$. Small changes in productivity then do not greatly affect union utility. A small decrease in the foreign wage level, in contrast, leads to a further decrease in the already small base of firms, 
greatly affecting total utility, and therefore leading to large adjustments of the optimal union wage demand in an attempt to preserve employment. Wage oriented unions make use of the closedness of the economy to inflate wage demands, but they skate on thin ice: small changes in foreign wages greatly affect union utility by causing small changes in the international distribution of firms, thus requiring large adjustment in the optimal union wage demand.

If unions attach more weight to employment $(\gamma<1)$, the term $-\epsilon_{h}^{L}-\gamma$ in equation (4) remains positive even as $-\epsilon_{h}^{n}$ approaches zero for very high trade costs. Wage demands remain limited and foreign wages (which enter the expression for the union wage demand only through $-\epsilon_{h}^{n}$ ) then become irrelevant altogether to union wage demands when $\phi \approx 0$.

Following proposition summarises these results

Proposition 3 If unions are wage (employment) oriented, wages are unit (in-) elastic with respect to foreign wages in autarky, and in- (unit) elastic with respect to the alternative wage. Wages become less (more) sensitive to the level of foreign wages after trade liberalisation, and more (less) sensitive to the alternative wage.

The effect of trade on the sensitivity of union wages with respect to the alternative wage (labour productivity) follow directly from proposition 1.

We do not claim the chosen framework is unique in making some of these predictions. Consider the case, for example, where unions set employment as well as wages. Labour demand $L$ in equation (2) then is assumed fixed when determining the optimal wage. Following the same steps as before then shows

$$
\epsilon_{f}^{h}=\frac{\gamma(\phi+m) f}{\gamma(\phi+m) f+\phi a},\left.\quad \epsilon_{f}^{h}\right|_{\phi=0}=1 \quad \text { and } \quad \frac{\mathrm{d} \epsilon_{f}^{h}}{\mathrm{~d} \phi}=\frac{-\gamma m f a}{(\gamma(\phi+m) f+\phi a)^{2}}<0 .
$$

And the same results as in the case of a wage biased union therefore hold.

\section{Empirical Framework}

In this section some of the predictions of the small model from the previous section are tested using aggregate data on 12 industries in 13 EU-countries for the years 1980-2001. We proceed in three steps. Firstly, bilateral sector-level intra-EU trade data is used to show that intra-EU trade costs have significantly declined over the last decades. Secondly, we argue that aggregate employment has become more sensitive to international relative wage cost differentials in those sectors and countries which experienced the largest drop in trade costs. Thirdly, it is shown that the sensitivity of wages with respect to changes in 
local labour productivity and the wage level in neighbouring countries has changed as trade was liberalised. There exist important differences between member states.

Sectoral data on employment, wages and productivity was taken from the EUKLEMS database (see Timmer et al., 2007). Market access and trade costs were calculated using the CEPII trade and production dataset assembled by Mayer et al. (2008). The sectors used are 12 2-digit NACE manufacturing sectors, except for the sectors 17-18, 21-22, 27-28, 30-33, and 34-35 which had to be aggregated due to data limitations. Sectors 23 (coke, refined petroleum products and nuclear fuel) and 16 (manufacture of tobacco products) were excluded. We use data from all EU15 member states, excluding Luxembourg and Greece for which insufficient trade data was available. ${ }^{4}$ As we require complete series the time-frame had to be limited to the years 1980-2001 and some country/sector combinations are not included (see table 8 in the appendix for a list of sectors and countries included in the sample). Throughout, although our theoretical predictions pertain to sector-level union wages, we consider sector level data which will be comprised of unionised and non-unionised firms and sub-sectors. We believe this is justified in that most sectors are unionised to a certain degree in the EU, and contracts in non-unionised firms are often subject to conditions which have been established by union bargaining at the sector level. Moreover, governments and other agents may in effect mimic the derived union behaviour (cfr. the example of Belgium given in the introduction). Both the CEPII and EUKLEMS dataset are publicly available for download. STATA code showing how the results in this section were obtained are available from the author on request.

\subsection{The evolution of intra-EU trade costs}

In typical economic geography models with Dixit-Stiglitz monopolistic competition and CES demand, a parameter $\phi=\tau^{1-\sigma}$ is used to express the 'freeness of trade'. Here $\tau$ are iceberg transport $\operatorname{costs}(\tau>1$ units of a good have to be shipped to sell 1 unit at the destination) and $\sigma>1$ is the familiar elasticity of substitution between CES varieties. $\phi$ is decreasing in transport costs and is bounded between 0 (autarky) and 1 (perfectly free trade). As shown by Head and Mayer (2004) the trade freeness $\phi_{n j i t}$ between countries $n$ and $j$ in sector $i$ and year $t$ can be estimated under reasonable assumptions, using only trade and production data. These authors show

$$
\phi_{n j i t}=\sqrt{\frac{m_{n j i t} m_{j n i t}}{m_{n n i t} m_{j j i t}}},
$$

$\overline{4}$ This leaves Austria, Belgium, Denmark, Finland, France, Germany, Ireland, Italy, the Netherlands, Portugal, Spain, Sweden and the United Kingdom in the sample. 
where $m_{n j i t}$ is the value of exports from $n$ to $j$ in sector $i$ and year $t$ and $m_{n n i t}$ is the value of country $n$ 's production net of exports (which can be understood as 'exports to self'). In most studies the parameter $\phi$ is calculated bilaterally. For our purposes, however, it proves more practical to treat all EU trading partners of a country as a rest-of-the-world aggregate.

Figure 2 shows $\phi$ for a selection of EU member states, aggregating trade flows over all manufacturing sectors. A clear upward trend is apparent, and
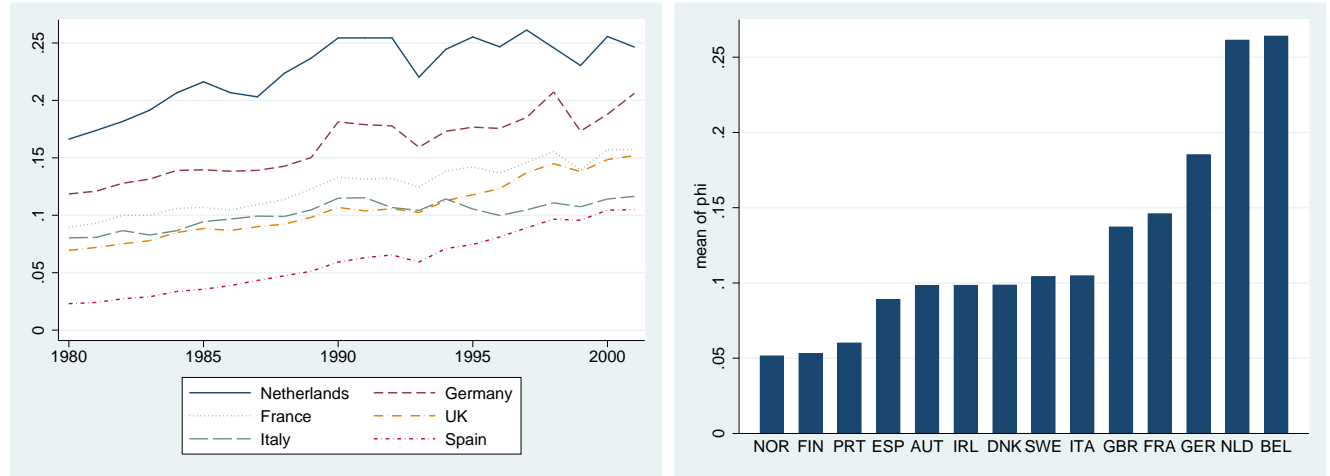

Fig. 2. The evolution of $\phi$ in some large EU member states (left) and a comparison of levels in 1999 for all countries in the sample, plus Norway.

new member states such as Spain (joined 1986) show an impressive increase in trade freeness, especially in relative terms. Clearly, long-time EU-member states and countries located close to the EU economic core regions have higher values of $\phi$ compared to more peripheral and non-member countries, such as Norway which was added for comparison. ${ }^{5}$ Large differences between sectors are revealed when estimating $\phi$ on the sectoral level, with trade freeness ranging from 0.016 for 'publishing, printing and reproduction of recorded media' to 0.28 for 'machinery and equipment'. ${ }^{6}$

Summarising, the trade data reveals both a significant decrease in intra-EU trade costs over the last two decades and the existence of substantial differences in the level and evolution of intra-EU trade freeness between member states and industries. This confirms the European integration process can be used as an interesting experiment to analyse the labour market effects of economic integration.

\footnotetext{
5 Note that for Finland, for example, trade with neighbouring countries such as Russia is not considered. Our estimate of $\phi$ for peripheral countries would underestimate their openness with respect to the world as a whole, but rather serves as a proxy for openness with respect to the EU15.

6 These numbers are for France in 1999.
} 
3.2 Economic integration and the effect of relative wages on aggregate employment

Log-linearising aggregate labour demand assuming $L=h^{-\epsilon}$ and using the specification for the number of firms in the country from equation (3) (while ignoring the effect of $\phi$ for now) suggests using following estimation equation for sectoral labour demand in country $k$, sector $i$ and year $t$

$$
\log L_{k i t} n_{k i t}=\beta_{0}+\beta_{1} \log \left(h_{k i t}\right)+\beta_{2} \log \left(h_{k i t} / f_{k i t}\right)+\beta_{3} \log \left(m_{k i t}\right)+\epsilon_{k i t} .
$$

This specification allows to differentiate between what might be called the national and international effect of wage changes. The coefficient $\beta_{1}$ measures $-\epsilon$, the effect of a wage increase on firm level labour demand, keeping the international wage differential $h / f$ and thus the distribution of firms $n$ fixed. A change in relative wages $h / f$ for a given level of local wages, in contrast, affects only the number of firms $n$ in a country but leaves the firm level labour demand unaffected. The coefficient $\beta_{2}$ captures how a relative wage change affects aggregate labour demand through $n$, keeping local wages fixed. The coefficient $\beta_{3}$ corresponds to the effect of an increase in the relative market size of a country on its sectoral employment. In our simple model an increase in $m$ only increases the number of firms $n$ in a country and leaves the typical firm size unaffected. ${ }^{7}$

The effect of a change in the relative wage $h / f$ is predicted to increase with freer trade. Although the effect of market size $m$ on $n$ is constant in our simple model, most models of economic geography predict the effect of market size on the distribution of firms to increases with freer trade. We therefore add interaction terms of the relative wage and market size with $\phi$. Moreover, although we abstracted from labour productivity in describing the location choice of firms, in reality firms are likely to consider wages relative to labour productivity when determining the total cost of production in a location. We therefore add local labour productivity and relative labour productivity as explanatory variables.

As the international distribution of firms and labour demand is likely to respond slowly to changes in factor prices and short run adjustment might significantly differ from the long-run dynamics we write the extended estimation

\footnotetext{
$\overline{7}$ This is the case in the long run equilibrium of the footloose capital model of Martin and Rogers (1995) as well, for example.
} 
equation (8) in an error-correction form:

$$
\begin{aligned}
\Delta \log n_{k i t} L_{k i t}=\alpha_{0} & +\sum_{j=0}^{1}\left[\xi_{j} \Delta x_{k i t}+\xi_{j}^{\prime} \Delta \phi_{k i t} x_{k i t}\right] \\
& +\alpha_{e c} \log n_{k i t-1} L_{k i t-1}+\alpha x_{k i t-1}+\alpha^{\prime} \phi_{k i t-1} x_{k i t-1} \\
& +\nu_{k i}+\mu_{t}+\eta_{k} t+\epsilon_{k i t}
\end{aligned}
$$

where $n L$ is measured as the aggregate sector-level total hours worked (loghours) and $x$ is a vector of explanatory variables in logs containing real wages logwage, wages relative to the foreign wage level logrelwage, labour productivity loglp, relative labour productivity logrellp, a measure of market access logaccess and the estimated trade freeness in levels $\phi$. Foreign variables are calculated treating all other countries as a rest-of-the-world aggregate. More details on how these variables are defined are available in the data appendix. The $\xi$ parameters correspond to the short run effects. The parameters $\alpha$ estimate the long-run relationship between the variables in levels, controlling for the short run adjustments. They relate to equation (8) via, for example for the element of $\alpha$ measuring the effect of a change in the local wage $h, \beta_{1}=-\alpha_{h} / \alpha_{e c}{ }^{8}$ The coefficient $\alpha_{e c}$ measures the speed of adjustment toward the long-run equilibrium. We add a country-sector specific constant $\left(\nu_{k i}\right)$, time dummies $\left(\mu_{t}\right)$ and allow for a country specific time trend by including $\eta_{k} t$. The $\epsilon_{k i t}$ capture residual error.

Table 1 shows the results of estimating the above error correction model by OLS. The estimates of the long-run parameters are given separately in the right panel of the table. In the remainder of the paper we will mostly immediately report the long-run estimates.

An important aspect in estimating relationships between long-run time series is the risk of spurious estimation results in case some of the variables are non-stationary. After confirming the existence of a unit root in the aggregate employment, wages and labour productivity series, we tested the null of nocointegration using the residual-based panel cointegration test of Kao (1999) and the test of Persyn and Westerlund (2008) which considers the speed and significance of the adjustment towards the long-run equilibrium relationship. The results were mixed, with the Kao (1999) test strongly rejecting the null of no-cointegration, while the Persyn and Westerlund (2008) test is not able to reject the series are not cointegrated. ${ }^{9}$

\footnotetext{
8 This can easily be verified by assuming all differenced variables equal zero in the error-correction equation.

9 A possible cause might be the combination of a large number of covariates and the short length of the series is weakening the power of the more structural test of Persyn and Westerlund (2008). The Persyn and Westerlund (2008) test also suffers
} 


\begin{tabular}{|c|c|c|c|}
\hline \multicolumn{2}{|c|}{ Dependent variable: $\Delta$ loghours } & & \\
\hline \multirow{26}{*}{ 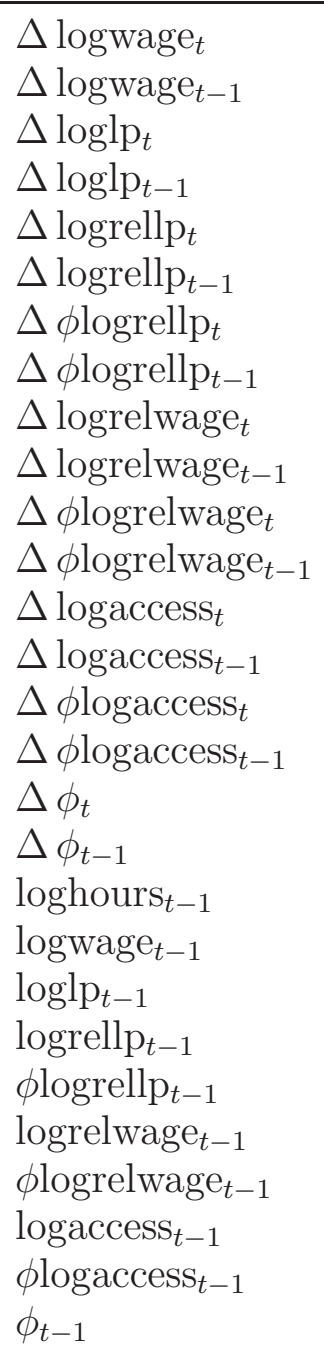 } & \multirow{7}{*}{$\begin{array}{c}0.0556 \\
0.110^{* *} \\
-0.0522 \\
0.141^{* * *} \\
-0.0173 \\
-0.0715^{* *} \\
0.365^{* * *} \\
-0.0373\end{array}$} & & \\
\hline & & \multicolumn{2}{|c|}{ Dependent variable: loghours } \\
\hline & & \multirow{2}{*}{ logwage } & -0.471 \\
\hline & & & $(0.379)$ \\
\hline & & \multirow{3}{*}{$\log l p$} & \\
\hline & & & -0.624 \\
\hline & & & $(0.508)$ \\
\hline & $-0.0920^{* *}$ & \multirow[t]{2}{*}{ logrellp } & $1.065^{* *}$ \\
\hline & $-0.156^{* * *}$ & & $(0.487)$ \\
\hline & $-0.293^{* *}$ & \multirow{3}{*}{$\phi$ logrellp } & \\
\hline & 0.136 & & $6.262^{* * *}$ \\
\hline & $0.137^{* * *}$ & & \\
\hline & $0.0488^{* * *}$ & \multirow{2}{*}{ logrelwage } & 0.175 \\
\hline & $0.120^{* *}$ & & $(0.332)$ \\
\hline & -0.0159 & \multirow{3}{*}{$\phi$ logrelwage } & \\
\hline & 0.189 & & $-7.250^{* * *}$ \\
\hline & 0.245 & & $(1.884)$ \\
\hline & $-0.0442^{* * *}$ & \multirow{2}{*}{ logaccess } & $0.525^{* * *}$ \\
\hline & -0.0208 & & $(0.200)$ \\
\hline & -0.0276 & \multirow{3}{*}{$\phi$ logaccess } & \\
\hline & $0.0471^{* *}$ & & $2.501^{* * *}$ \\
\hline & $0.277^{* * *}$ & & $(0.730)$ \\
\hline & 0.00773 & \multirow{2}{*}{$\phi$} & \\
\hline & $-0.320^{* * *}$ & & $(7.657)$ \\
\hline & $\begin{array}{l}0.0232^{* *} \\
0111^{* * * *}\end{array}$ & \multirow{2}{*}{\multicolumn{2}{|c|}{$\begin{array}{l}\text { Standard errors in parentheses } \\
{ }^{*} p<0.1,{ }^{* *} p<0.05,{ }^{* * *} p<0.01\end{array}$}} \\
\hline & $\begin{array}{l}0.111^{\text {Fat }} \\
-0.218\end{array}$ & & \\
\hline Observations & 2594 & & \\
\hline
\end{tabular}

Table 1 The effect of cost competitiveness and market access on sectoral labour demand.

Bearing in mind the mixed results from the cointegration tests, the results do suggest the simple assumptions of our model hold: as trade freeness increases, the attractiveness of a country in terms of its relative wage and productivity becomes more important in explaining aggregate labour demand. There is evidence of a home market effect in that freer trade increases the effect of changes in the local market size on the aggregate labour demand.

from low power if the covariates in the error-correction equation are error-correcting as well. 


\subsection{Economic integration and union wage demands}

So far we have established empirically that trade costs have significantly declined. We also found that this is accompanied by an increase in the sensitivity of aggregate of employment with respect to international differences in labour costs, which offers support for this assumption of our small model on the location of economic activity. As we argued in our theoretical section, a monopoly union should take firm mobility into account when setting wages. Our theoretical model makes clear predictions on the resulting relationship between union wage demands, labour productivity and foreign wages, and how this relationship changes after trade liberalisation. We estimate following relationship, which derives directly from equation (5) or proposition 3.

$$
\begin{aligned}
\log h_{k i t}=\beta_{0} & +\beta_{1} \log \left(a_{k i t}\right)+\beta_{1}^{\prime} \phi_{k i t} \log \left(a_{k i t}\right)+\beta_{2} \log \left(f_{k i t}\right)+\beta_{2}^{\prime} \phi_{k i t} \log \left(f_{k i t}\right) \\
& +\beta_{3} \phi_{k i t}+\nu_{k i}+\mu_{t}+\eta_{k} t+\epsilon_{k i t} .
\end{aligned}
$$

The predictions from theory are that if unions have strong preferences for wages we should observe $\beta_{1}=0$ and $\beta_{2}=1$ as these coefficients correspond to autarky. The effect of labour productivity on wages will then increase for freer trade $\left(\beta_{1}^{\prime}>0\right)$ and foreign wages will become less relevant to the optimal union wage demand $\left(\beta_{2}^{\prime}<0\right)$. In case unions have strong preferences for employment, the opposite holds: $\beta_{1}=1, \beta_{2}=0, \beta_{1}^{\prime}<0$ and $\beta_{2}^{\prime}>0$.

Table 2 shows the results of estimating the above equation in an error cor-

\begin{tabular}{|c|c|c|c|}
\hline \multicolumn{2}{|c|}{ Dependent variable: $\Delta$ logwage } & & \\
\hline \multirow{8}{*}{$\begin{array}{l}\Delta \operatorname{loglp}_{t} \\
\Delta \operatorname{loglp}_{t-1} \\
\Delta \phi \operatorname{loglp}_{t} \\
\Delta \phi \operatorname{loglp}_{t-1} \\
\Delta \operatorname{logwageEU}_{t} \\
\Delta \operatorname{logwageEU}_{t-1} \\
\Delta \phi \operatorname{logwageEU}_{t} \\
\Delta \phi \operatorname{logwageEU}_{t-1} \\
\Delta \phi_{t} \\
\Delta \phi_{t-1} \\
\operatorname{logwage}_{t-1} \\
\operatorname{loglp}_{t-1} \\
\phi \operatorname{loglp}_{t-1} \\
\operatorname{logwageEU}_{t-1} \\
\phi \operatorname{logwageEU}_{t-1} \\
\phi_{t-1}\end{array}$} & \multirow{8}{*}{$\begin{array}{c}0.516^{* * *} \\
0.000353 \\
0.140 \\
-0.0178 \\
0.246^{* * *} \\
-0.0478 \\
-0.518^{* *} \\
0.174 \\
-0.732^{* * *} \\
0.168 \\
-0.193^{* * *} \\
0.124^{* * *} \\
0.159^{* *} \\
0.0558^{* * *} \\
-0.255^{* *} \\
-0.224^{*}\end{array}$} & \multicolumn{2}{|c|}{ Dependent variable: logwage } \\
\hline & & \multirow[t]{2}{*}{$\log \operatorname{lp}$} & $\begin{array}{l}0.642^{* * *} \\
(0.0492)\end{array}$ \\
\hline & & & $(0.0492)$ \\
\hline & & $\phi \log l p$ & $\begin{array}{l}0.823^{* * *} \\
(0.317)\end{array}$ \\
\hline & & logwageEU & $\begin{array}{c}0.288^{* * *} \\
(0.0973)\end{array}$ \\
\hline & & $\phi$ logwageEU & $\begin{array}{c}-1.318^{* *} \\
(0.520)\end{array}$ \\
\hline & & $\phi$ & $\begin{array}{r}-1.159^{*} \\
(0.607)\end{array}$ \\
\hline & & \multirow{2}{*}{\multicolumn{2}{|c|}{$\begin{array}{l}\text { Standard errors in parentheses } \\
{ }^{*} p<0.1,{ }^{* *} p<0.05,{ }^{* * *} p<0.01\end{array}$}} \\
\hline Observations & 2594 & & \\
\hline
\end{tabular}
rection form. For this wage regression, both the Kao (1999) and Persyn and

Table 2 The effect of labour productivity, foreign wages and trade openness. 
Westerlund (2008) test strongly reject the null of no cointegration.

The results do not allow to draw a straightforward conclusion. On average, trade liberalisation seems to have had a downward effect on wages. The fact the coefficient on labour productivity is rather high compared to the low coefficient on the level of foreign wages suggests union preferences are biased toward employment. The effect of freer trade on the effect of these variables, however, suggests unions are wage oriented. An obvious cause for these mixed results could be the fact union preferences are heterogeneous across EU member states and sectors, and the above results would suffer from some aggregation bias.

\subsubsection{Heterogeneous union preferences}

To investigate whether the heterogeneity of union preferences is affecting our results, we split the sample in two groups of countries, depending on whether they have a statutory minimum wage or not. Judging from the unemployment levels in 1980 reported in table 7 (the first year in our sample) in the appendix, employment in countries with a statutory minimum wage bore a larger part of the burden of the economic downturn in this period compared to countries without a statutory minimum wage. If the presence of a statutory minimum wage proxies for the relative union preference for wages relative to employment, we should observe different coefficients which are more in line with the theoretical predictions in both groups.

The first column of table 3 shows the long run coefficients of the wage regression for the UK, the Netherlands, France, Ireland, Portugal, Belgium and Spain, which have a statutory minimum wage. These results contrast with the second column, showing the results for Austria, Sweden, Germany, Finland, Denmark and Italy. Splitting the sample shifts the coefficients in the expected direction. In the group of countries with a statutory minimum wage the coefficient on labour productivity is smaller compared to countries without minimum wages, but remains large and significantly different from zero. Similarly for the coefficient on foreign wages: it is substantially larger compared to countries without minimum wages, but is significantly different from one. The effect of freer trade is as predicted in both groups, except for the effect on the labour productivity elasticity in the group of countries without a minimum wage, which is not significantly different from zero. In the minimumwage group the coefficients on productivity and foreign wages are closer to $1 / 2$ than their theoretically predicted values of 0 and 1 .

A first straightforward explanation for these observations is that the groups of countries are still heterogeneous in terms of union preferences. We will attempt to deal with this issue by introducing a better sector/country specific (rather than just country specific) proxy for the union relative preference for wages 


\begin{tabular}{lcc}
\hline \multicolumn{3}{l}{ Dependent variable: logwage } \\
\hline & $\begin{array}{c}\text { Statutory } \\
\text { minimum wage }\end{array}$ & $\begin{array}{c}\text { No statutory } \\
\text { minimum wage }\end{array}$ \\
\hline loglp & $0.634^{* * *}$ & $0.718^{* * *}$ \\
& $(0.0769)$ & $(0.0601)$ \\
$\phi$ loglp & $0.998^{* *}$ & 0.305 \\
& $(0.473)$ & $(0.462)$ \\
logwageEU & $0.487^{* * *}$ & 0.0273 \\
& $(0.189)$ & $(0.0896)$ \\
$\phi$ logwageEU & $-3.017^{* * *}$ & $0.943^{*}$ \\
& $(0.907)$ & $(0.552)$ \\
$\phi$ & $-3.339^{* * *}$ & $1.655^{* * *}$ \\
& $(1.034)$ & $(0.628)$ \\
\hline Observations & 1339 & 1255 \\
\hline Standard errors in parentheses & \\
${ }^{*} p<0.1,{ }^{* *} p<0.05,{ }^{* * *} p<0.01$ &
\end{tabular}

Table 3 The effect of labour productivity, foreign wages and trade openness.

later on.

A second explanation is the fact it is difficult to estimate the effect for $\phi=0$ as this value is out-of-sample: no country or industry is completely isolated in our dataset. For values of $\phi$ close to 0 , but not exactly equal to $\phi$, equation (6) holds, and not equation (7). It are these values $\phi>0$ which we observe in the data. Unless unions have extreme preferences, we expect elasticities closer to $1 / 2$ for these strictly positive values of $\phi$.

Thirdly, as the predicted effect of $\phi$ on the coefficients is nonlinear, some bias can be expected due to the linear approximation used in our estimation. In fact, given the curvature in the predicted coefficient on productivity and foreign wages around $\phi=0$ (as shown in figure 1) we expect a linear approximation to underestimate the true value close to $\phi=0$ when the predicted coefficient is 1 , and expect an overestimate of the true value in case the predicted coefficient is $0 .{ }^{10}$ Adding interaction terms of labour productivity and foreign wages with the squared freeness of trade allows to evaluate the direction and importance of these nonlinear effects. Table 4 shows the results for the full sample and both groups separately. Splitting the sample shifts the coefficients in the predicted direction for all coefficients and considerably improves the fit. For countries without a statutory minimum wage, allowing for nonlinear effects makes the coefficients on labour productivity and foreign wages in autarky almost perfectly match the theoretical predictions. For countries with

\footnotetext{
${ }^{10}$ Imagine drawing a line through a point cloud around the theoretically predicted values of the elasticities in figure 1 . Then consider where it would cross the Y-axis.
} 


\begin{tabular}{|c|c|c|c|}
\hline \multicolumn{4}{|c|}{ Dependent variable: logwage } \\
\hline & $\begin{array}{c}\text { Full } \\
\text { sample }\end{array}$ & $\begin{array}{c}\text { Statutory } \\
\text { minimum wage }\end{array}$ & $\begin{array}{l}\text { No statutory } \\
\text { minimum wage }\end{array}$ \\
\hline $\log l p$ & $\begin{array}{c}0.548^{* * *} \\
(0.0702)\end{array}$ & $\begin{array}{c}0.433^{* * *} \\
(0.109)\end{array}$ & $\begin{array}{c}0.931^{* * *} \\
(0.0913)\end{array}$ \\
\hline$\phi \log l p$ & $\begin{array}{c}2.725^{* *} \\
(1.109)\end{array}$ & $\begin{array}{l}5.127^{* * *} \\
(1.681)\end{array}$ & $\begin{array}{c}-4.773^{* * *} \\
(1.654)\end{array}$ \\
\hline$\phi^{2} \log \operatorname{lp}$ & $\begin{array}{r}-6.665^{*} \\
(3.882)\end{array}$ & $\begin{array}{r}-14.45^{* *} \\
(5.849)\end{array}$ & $\begin{array}{l}17.32^{* * *} \\
(5.559)\end{array}$ \\
\hline logwageEU & $\begin{array}{c}0.438^{* * *} \\
(0.137)\end{array}$ & $\begin{array}{l}0.722^{* * *} \\
(0.240)\end{array}$ & $\begin{array}{c}-0.133 \\
(0.133)\end{array}$ \\
\hline$\phi$ logwageEU & $\begin{array}{c}-4.532^{* *} \\
(1.837)\end{array}$ & $\begin{array}{c}-9.273^{* * *} \\
(2.983)\end{array}$ & $\begin{array}{c}5.319^{* *} \\
(2.097)\end{array}$ \\
\hline$\phi^{2} \operatorname{logwageEU}$ & $\begin{array}{l}11.69^{*} \\
(6.187)\end{array}$ & $\begin{array}{c}23.27^{* *} \\
(10.40)\end{array}$ & $\begin{array}{r}-14.83^{* *} \\
(6.972)\end{array}$ \\
\hline$\phi$ & $\begin{array}{c}-2.790 \\
(2.252)\end{array}$ & $\begin{array}{r}-6.223 \\
(3.878)\end{array}$ & $\begin{array}{r}4.003^{*} \\
(2.198)\end{array}$ \\
\hline$\phi^{2}$ & $\begin{array}{c}6.972 \\
(7.161)\end{array}$ & $\begin{array}{c}13.25 \\
(12.39)\end{array}$ & $\begin{array}{r}-6.835 \\
(6.916)\end{array}$ \\
\hline Observations & 2594 & 1339 & 1255 \\
\hline
\end{tabular}

Table 4 The nonlinear effect of trade openness on the relationship between labour productivity, foreign wages and union wages, separately for countries with and without a statutory minimum wage (see table 7 in the data appendix).

a minimum wage those coefficients are still rather close to $1 / 2$, but are much more in line with the predictions compared to the linear specification.

To obtain groups which are more homogeneous with respect to union preferences and to illustrate the robustness of our results with respect to the chosen proxy for the relative wage preference of unions, we repeat the split sample analysis using the variability of wages relative to employment as a direct estimate of the union preferences. As shown by Pehkonen (1990) wages vary more than employment over the business cycle if unions are wage-oriented, and viceversa with employment oriented unions. As an estimate of the variability of wages and employment, we take the standard deviation of the residuals of a sector/country specific regression of both variables in logs on a constant and linear time-trend. This provides us with a country/sector specific estimate of the relative variability of wages. We then split the sample, assigning half of the country/sector combinations to two groups according to their estimated union wage preference. These two groups are rather heterogeneous in terms of the countries and sectors included as can be seen in table 8 in the appendix, but are designed to be more homogeneous with respect to the underlying union 
preferences. Figure 3 shows the sector/country combinations in our dataset the highest (left panel) and lowest (right panel) variability of wages relative to employment around a linear time-trend. The results of the split-sample analysis
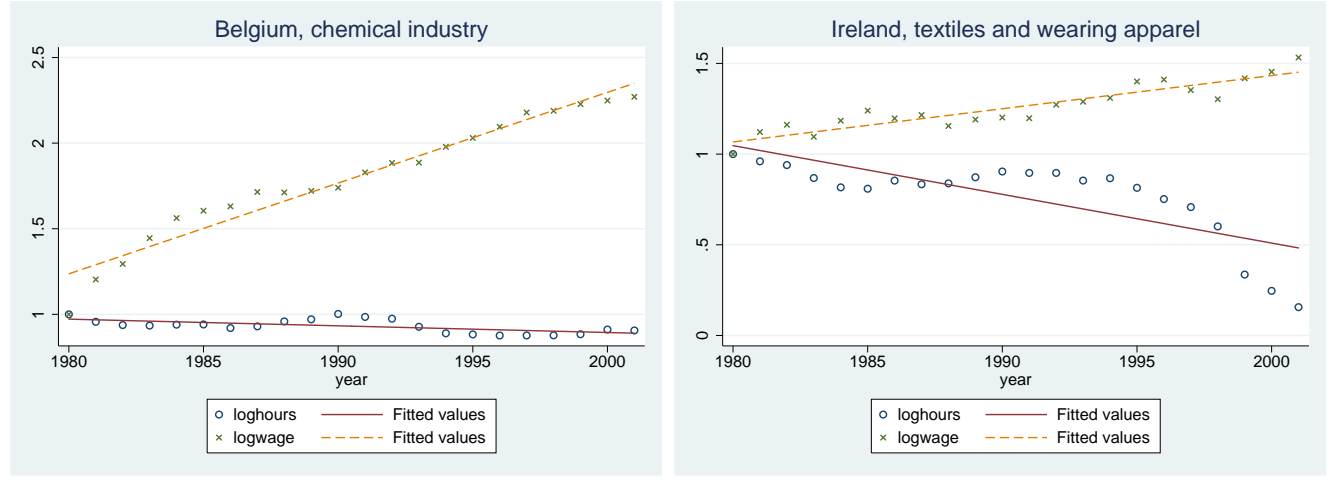

Fig. 3. The sector/country combinations with the highest (left panel) and lowest (right panel) variability of wages relative to employment

using this new proxy for union preferences is reported in the OLS columns of table 5. Despite the substantial rearrangement of the composition of both groups ${ }^{11}$ the estimated coefficients remain very much in line with the predictions. The fact the standard error of the estimated coefficients declines in all cases strongly suggests both groups are more homogeneous regarding union preferences compared to the case where we used the presence of a statutory minimum wage as an indicator of a relatively wage-oriented union.

\subsubsection{Endogenous regressors}

The error-correction framework we have used so far is flexible in allowing the relationship between the variables in differences to differ from the relationship in levels, thus allowing the short and long run dynamics to differ. Other popular techniques for estimating cointegration relationships, such as the panel dynamic OLS (PDOLS) method of Mark and Sul (2003) typically restrict short and long run dynamics to be identical (a common factor restriction).

An issue we have ignored so far is the possibility of weak exogeneity or endogeneity of regressors, which would arise if the regressors themselves are error-correcting, or if innovations in the regressors are correlated with leads or lags of the error term in the error correction equation. Controlling for these forms of endogeneity is an important goal of estimators such as Mark and Sul (2003). Although we believe the risk of endogenous regressors is limited for our specific application, we repeated the last split-sample regression with nonlinear effects using the panel dynamic OLS estimator. The underlying idea of

\footnotetext{
${ }^{11}$ The results are robust to excluding France and Belgium, for which all sectors were assigned to the 'high wage variability' group and were also in the 'statutory minimum wage' group.
} 
this method is to estimate the cointegration equation directly (imposing the common factor restriction), augmenting it with leads and lags of the first differences of the dependent variable and all covariates, while allowing the dependency on these additional variables to be specific to the cross-sectional units (to control for endogeneity). This requires a large number of coefficients to be estimated, especially as in our case the number of covariates is rather high and we have a maximum of only 21 observations per series. Including the contemporaneous value, a single lag and a single lead of the differenced dependent variable and all covariates (without interaction terms) requires the estimation of 971 parameters in the high wage variability group, for example. Table 5 shows the results using the PDOLS estimation remain in line with our previous findings.

\begin{tabular}{|c|c|c|c|c|}
\hline \multicolumn{5}{|c|}{ Dependent variable: logwage } \\
\hline & \multicolumn{2}{|c|}{ High wage variability } & \multicolumn{2}{|c|}{ Low wage variability } \\
\hline & OLS & PDOLS & OLS & PDOLS \\
\hline $\log l p$ & $\begin{array}{c}0.442^{* * *} \\
(0.0980)\end{array}$ & $\begin{array}{c}0.331^{* * *} \\
(0.0505)\end{array}$ & $\begin{array}{c}0.692^{* * *} \\
(0.0933)\end{array}$ & $\begin{array}{c}0.759^{* * *} \\
(0.0536)\end{array}$ \\
\hline$\phi \log l p$ & $\begin{array}{l}6.403^{* * *} \\
(1.534)\end{array}$ & $\begin{array}{l}2.811^{* * *} \\
(0.862)\end{array}$ & $\begin{array}{c}-3.865^{* *} \\
(1.670)\end{array}$ & $\begin{array}{c}-4.714^{* * *} \\
(0.959)\end{array}$ \\
\hline$\phi^{2} \log \operatorname{lp}$ & $\begin{array}{r}-22.37^{* * *} \\
(5.676)\end{array}$ & $\begin{array}{c}-4.982 \\
(3.317)\end{array}$ & $\begin{array}{c}20.83^{* * *} \\
(5.714)\end{array}$ & $\begin{array}{c}17.74^{* * *} \\
(3.465)\end{array}$ \\
\hline logwageEU & $\begin{array}{l}0.828^{* * *} \\
(0.222)\end{array}$ & $\begin{array}{l}0.536^{* * *} \\
(0.103)\end{array}$ & $\begin{array}{c}0.0521 \\
(0.164)\end{array}$ & $\begin{array}{c}-0.138^{*} \\
(0.0762)\end{array}$ \\
\hline$\phi$ logwageEU & $\begin{array}{c}-12.49^{* * *} \\
(2.899)\end{array}$ & $\begin{array}{c}-3.688^{* *} \\
(1.706)\end{array}$ & $\begin{array}{c}3.154 \\
(2.478)\end{array}$ & $\begin{array}{l}4.537^{* * *} \\
(1.252)\end{array}$ \\
\hline$\phi^{2}$ logwageEU & $\begin{array}{l}41.10^{* * *} \\
(10.64)\end{array}$ & $\begin{array}{c}7.184 \\
(6.450)\end{array}$ & $\begin{array}{r}-13.91^{*} \\
(7.791)\end{array}$ & $\begin{array}{c}-14.90^{* * *} \\
(4.069)\end{array}$ \\
\hline$\phi$ & $\begin{array}{c}-9.773^{* * *} \\
(3.717)\end{array}$ & $\begin{array}{c}0.0990 \\
(2.245)\end{array}$ & $\begin{array}{c}1.672 \\
(2.710)\end{array}$ & $\begin{array}{c}1.179 \\
(1.426)\end{array}$ \\
\hline$\phi^{2}$ & $\begin{array}{c}31.94^{* *} \\
(12.46) \\
\end{array}$ & $\begin{array}{r}-1.959 \\
(7.835) \\
\end{array}$ & $\begin{array}{r}-1.938 \\
(8.333) \\
\end{array}$ & $\begin{array}{c}-0.721 \\
(4.373) \\
\end{array}$ \\
\hline Observations & 1282 & 1282 & 1311 & 1311 \\
\hline
\end{tabular}

Table 5 Separate estimation for countries and sectors depending on the cyclical variability of wages relative to employment.

\subsubsection{Quantifying the results}

Our base regression shown in table 2 predicts a large increase of $\phi$ by 0.25 from 0.02 to 0.27 (which correspond to the 5 th and 95th percentile of $\phi$ respectively) implies a decrease in wages of about 29 percent as a direct effect. In most 
specifications the estimated downward effect was much larger in countries with a statutory minimum wage (which we assumed have wage-oriented unions).

Trade freeness has a significant effect on the sensitivity of wages with respect to labour productivity and foreign wages. Consider for example the PDOLS estimation for wage oriented countries in table 5 . The elasticity of wages with respect to labour productivity changes from 0.38 to 0.73 when $\phi$ changes from 0.02 to 0.27 . The foreign wage level becomes almost irrelevant as the estimated elasticity drops from 0.47 to 0.06 .

This paper has focused mainly on the wage effects of trade integration. As for the employment effects, table 1 showed that, on average, trade liberalisation is estimated to have had a negative impact on employment, but the effect was non-significant. This contrasts to our simple union model, where trade liberalisation always implies more wage discipline and hence an increased demand for labour.

We now repeat the estimation of aggregate labour demand, but now split sectors and countries according to their estimated relative union preference for wages. Table 6 shows that, as expected, the employment effect of trade has been overwhelmingly positive where unions are wage oriented, as trade had the largest disciplining effect on union wage demands in these countries and sectors. For the employment oriented group, the results run contrary to the predictions, but are not significant.

\section{Conclusion}

In this paper we have attempted to shed light on how trade liberalisation acts as a wage disciplining device. We started by assuming wages are set by a monopoly union which takes into account the international mobility of production. With some minimal assumptions on the structure of union preferences, we are able to predict that as trade costs decline unions lower their wage demands and -if unions care more about wages than employment- union wages move more closely in line with labour productivity after trade liberalisation. Foreign wages simultaneously become less relevant to the optimal union wage demand.

We then showed these theoretical predictions are broadly supported by an analysis of long sector-level time-series for a selection of EU member states. We consider some extensions of the model which confirm the validity of our framework. Taking the existence of a statutory minimum wage and the relative wage variability of wages relative to employment in a country as a proxy for the relative union preference for wages relative to employment, the predictions 


\begin{tabular}{|c|c|c|}
\hline \multicolumn{3}{|c|}{ Dependent variable: loghours } \\
\hline & $\begin{array}{l}\text { High wage } \\
\text { variability }\end{array}$ & $\begin{array}{l}\text { Low wage } \\
\text { variability }\end{array}$ \\
\hline logwage & $\begin{array}{r}-0.137 \\
(0.223)\end{array}$ & $\begin{array}{r}-1.026 \\
(0.659)\end{array}$ \\
\hline $\operatorname{loglp}$ & $\begin{array}{c}-0.678^{* *} \\
(0.304)\end{array}$ & $\begin{array}{c}0.573 \\
(0.863)\end{array}$ \\
\hline logrellp & $\begin{array}{c}0.663^{* *} \\
(0.306)\end{array}$ & $\begin{array}{c}0.563 \\
(0.719)\end{array}$ \\
\hline$\phi$ logrellp & $\begin{array}{c}1.926^{* *} \\
(0.767)\end{array}$ & $\begin{array}{l}7.572^{* * *} \\
(2.800)\end{array}$ \\
\hline logrelwage & $\begin{array}{c}0.198 \\
(0.213)\end{array}$ & $\begin{array}{r}-0.177 \\
(0.486)\end{array}$ \\
\hline$\phi$ logrelwage & $\begin{array}{r}-1.866^{*} \\
(1.057)\end{array}$ & $\begin{array}{c}-5.596^{* *} \\
(2.796)\end{array}$ \\
\hline logaccess & $\begin{array}{l}0.574^{* * *} \\
(0.146)\end{array}$ & $\begin{array}{c}0.555^{*} \\
(0.288)\end{array}$ \\
\hline$\phi$ logaccess & $\begin{array}{c}0.0589 \\
(0.414)\end{array}$ & $\begin{array}{c}3.899^{* * *} \\
(1.283)\end{array}$ \\
\hline$\phi$ & $\begin{array}{l}10.02^{* *} \\
(5.067)\end{array}$ & $\begin{array}{c}-19.58 \\
(13.08)\end{array}$ \\
\hline Observations & 1282 & 1311 \\
\hline
\end{tabular}

Table 6 Separate aggregate labour demand estimation for countries and sectors depending on the cyclical variability of wages relative to employment.

of the model are confirmed in a split-sample analysis. The predicted nonlinear effect of trade on the elasticity of wages with respect to labour productivity and foreign wages is shown to be reflected in the data.

Our findings suggest a model where unions are setting wages while taking into account the international mobility of production provides a reasonable explanation of the behaviour of European wages during a period of intensive trade liberalisation. The economic integration process has made the average EU labour market more competitive in that wages move more in line with labour productivity. The estimated direct negative effect of freer trade on wages is significant in countries with wage oriented unions only. The effect trade has through changing the link between union wages and its determinants proves at least as important.

Wages in countries with wage oriented unions converge toward the perfectly competitive wage level after trade liberalisation. If technology is not too differ- 
ent between countries, this implies wage convergence. Simultaneously wages in these countries become less sensitive to foreign wages. This suggest that investigating the relationship between wages in different countries as a proof for factor price convergence can be misleading.

\section{References}

Abowd, J. M., Lemieux, T., 1990. The effects of international competiton on collective bargaining outcomes: A comparison of the United States and Canada. NBER Working Paper (3352).

Andersen, T. M., Haldrup, N., Sørensen, J. R., 2000. Labour market implications of EU product market integration. Economic Policy 15 (30), 105-134.

Berger, H., Westermann, F., 2001. Factor price equalization? The cointegration approach revisited. Review of World Economics 137 (3), 525-536.

Boulhol, H., Dobbelaere, S., Maioli, S., 2007. Imports as product and labour market discipline. Working Papers of Faculty of Economics and Business Administration, Ghent University, Belgium 07/479.

Burgman, T., Geppert, J., 1993. Factor price equalization: a cointegration approach. Review of World Economics 127 (3), 472-487.

Feenstra, R. C., Hanson, G. H., 2004. Global production and inequality: A survey of trade and wages. In: Choi, E. K., Harrigan, J. (Eds.), Handbook of International Economics. Basil Blackwell, Oxford, pp. 146-185.

Fontagné, L., Mirza, D., 2007. International trade and rent sharing among developed and developing countries. Economic Modelling 24 (3), 523-558.

Gremmen, H. J., 1985. Testing the factor price equalization theorem in the EC: An alternative approach. Journal of Common Market Studies 23 (3), $277-286$.

Grossman, G., 1987. The employment and wage effects of import competition in the United States. Journal of International Economic Integration 2 (1), $1-23$.

Head, K., Mayer, T., 2004. The empirics of agglomeration and trade. In: Henderson, J. V., Thisse, J. F. (Eds.), Handbook of Regional and Urban Economics. Elsevier, pp. 2609-2669.

Hoekman, B., Winters, A. L., 2005. Trade and employment: Stylized facts and research findings. United Nations, Department of Economics and Social Affairs Working Papers (7).

Jung, C., Doroodian, K., 2000. Labor costs convergence in manufacturing between North America and Western Europe, 1960-1991. Journal of Economic Studies 27, 514-525.

Kao, C., 1999. Spurious regression and residual-based tests for cointegration in panel data. Journal of Econometrics 90 (1), 1-44.

Layard, R., Nickell, S., Jackman, R., 2005. Unemployment. Oxford University Press. 
Leamer, E., 1995. The Heckscher-Ohlin model in theory and practice. Princeton Studies in International Economics (77).

Macpherson, D. A., Stewart, J. B., 1990. The effect of international competition on union and nonunion wages. Industrial and Labor Relations Review 43 (4), 434-446.

Mark, N. C., Sul, D., 2003. Cointegration vector estimation by panel DOLS and long-run money demand. Oxford Bulletin of Economics and Statistics 65 (5), 655-680.

Martin, P., Rogers, C., 1995. Industrial location and public infrastructure. Journal of International Economics 39, 335-51.

Mayer, T., Paillacar, R., Zignago, S., 2008. CEPII trade, production and bilateral protection database: Explanatory notes. Tech. rep., available at http://www.cepii.fr/anglaisgraph/bdd/TradeProd.

Mezzetti, C., Dinopoulos, E., 1991. Domestic unionization and import competition. Journal of International Economics 31, 79-100.

Pehkonen, J., 1990. Trade union objectives and the cyclical variability of wages and employment. Scandinavian Journal of Economics 92 (4), 573-86.

Persyn, D., Westerlund, J., 2008. Error-correction-based cointegration tests for panel data. Stata Journal 8 (2), 232-241.

Revenga, A. L., 1992. Exporting jobs? The impact of import competition on employment and wages in U.S. manufacturing. The Quarterly Journal of Economics 107 (1), 255-84.

Timmer, M., O'Mahony, M., van Ark, B., 2007. The EU KLEMS Growth and Productivity Accounts: An Overview. University of Groningen and University of Birmingham, downloadable at www.euklems.net.

Tovias, A., 1982. Testing factor price equalization in the EEC. Journal of Common Market Studies 20 (4), 375-388.

Webber, D., White, P., 2003. Regional factor price convergence across four major European countries. Regional Studies 37 (8), 773-782.

\section{Data Appendix}

\section{Variable definitions}

For Eurozone countries all nominal values were deflated using sector-country level producer price deflators. For Sweden, the UK and Denmark the constant local currency values where then converted to euros using a fixed conversion rate.

Wages are calculated as the total labour compensation per person engaged. Labour productivity is calculated as the amount of real output per person engaged. 
The foreign wage is calculated as a macro concept: for a country $i$ the foreign wage is the sum of total labour compensation in all other EU member states in the sample, divided by the sum of the number of persons engaged in these member states. This implies large countries have more weight in our measure of foreign wages.

For the market size $m_{n i t}$ we take the distance-weighted total demand for output of sector $i$, from the perspective of country $n$, in year $t$. It proxies for the market potential $m$ in the model. The distance weighted variables are calculated as follows

$$
\begin{aligned}
m_{n i t} & =\sum_{j} \omega_{n j} C_{j i t} \\
\omega_{n j} & =\left(\sum_{r \in n}\left(\operatorname{pop}_{r} / \operatorname{pop}_{n}\right) \sum_{k \in j}\left(\operatorname{pop}_{k} / \operatorname{pop}_{j}\right) d_{r k}\right) .
\end{aligned}
$$

Here $d_{r k}$ is the geographic distance between regions $r$ and $k$ in countries $n$ and $j$ respectively and $\operatorname{pop}_{z}$ is the population in region $z$. Data for $\omega_{n j}$ and the GDP were obtained from Mayer et al. (2008). $C_{j i t}$ is the total consumption in country $j$ of the output of the sector $i$ in year $t$. This type of weighting takes into account the distribution of demand among the regions bordering the country of interest. Belgium, for example, would have a larger market access than its GDP would suggest, as major industrialised and urbanised regions such as Paris, the German Ruhr area and the Netherlands are in close proximity.

\section{Minimum wages, unemployment $\& 5$ wage orientation}

Table 7 shows the unemployment rate of all countries included in the sample, whether the country has a statutory minimum wage, and whether it is wageoriented in that most of its sectors show a relatively high variability of wages over the business-cycle.

Table 8 shows which sector/country combinations were included in the sample. Combinations indicated by a $\mathrm{W}$ show a relatively high variability of wages over the business-cycle. An E stands for a high relative variability of employment. 


\begin{tabular}{ll}
\hline Austria & 1.85 \\
Sweden & 2.22 \\
Germany & 3.24 \\
Finland & 4.69 \\
United Kingdom* $^{*}$ & 5.71 \\
Netherlands $^{* \dagger}$ & 6.16 \\
France $^{* \dagger}$ & 6.51 \\
Denmark $^{\dagger}$ & 6.93 \\
Ireland $^{* \dagger}$ & 7.39 \\
Italy $^{\dagger}$ & 7.66 \\
Portugal $^{* \dagger}$ & 7.84 \\
Belgium $^{* \dagger}$ & 8.09 \\
Spain* $^{*}$ & 11.51 \\
\hline
\end{tabular}

Table 7 Unemployment rates (in \%) in 1980 (source: OECD). Countries with a statutory minimum wage are indicated by a star. Countries with a majority of sectors exhibiting large fluctuations in wages as compared to employment are indicated by $\dagger$.

\begin{tabular}{|c|c|c|c|c|c|c|c|c|c|c|c|c|c|c|}
\hline ector & & & & $\mathrm{SH}$ & & & & 5 & & 11 & 1 & & & T \\
\hline 15 & $\mathrm{E}$ & W & W & W & $\mathrm{E}$ & W & W & W & W & & & W & W & 11 \\
\hline $17 / 18$ & $\mathrm{E}$ & W & $\mathrm{E}$ & $\mathrm{E}$ & $\mathrm{E}$ & W & $\mathrm{E}$ & $\mathrm{E}$ & $\mathrm{E}$ & $\mathrm{E}$ & & W & $\mathrm{E}$ & 12 \\
\hline 19 & & & & $\mathrm{E}$ & $\mathrm{E}$ & W & $\mathrm{E}$ & $\mathrm{E}$ & & W & & $\mathrm{E}$ & & 7 \\
\hline 20 & $\mathrm{E}$ & W & W & $\mathrm{E}$ & $\mathrm{E}$ & W & $\mathrm{E}$ & $\mathrm{E}$ & $\mathrm{E}$ & W & W & W & $\mathrm{E}$ & 13 \\
\hline $21 / 22$ & W & W & W & $\mathrm{E}$ & W & W & W & $\mathrm{E}$ & $\mathrm{E}$ & $\mathrm{E}$ & $\mathrm{E}$ & W & W & 13 \\
\hline 24 & W & W & W & W & W & W & $\mathrm{E}$ & W & W & W & & W & $\mathrm{E}$ & 12 \\
\hline 25 & W & W & $\mathrm{E}$ & $\mathrm{E}$ & W & W & $\mathrm{E}$ & $\mathrm{E}$ & W & $\mathrm{E}$ & $\mathrm{E}$ & W & $\mathrm{E}$ & 13 \\
\hline 26 & $\mathrm{E}$ & W & $\mathrm{E}$ & $\mathrm{E}$ & $\mathrm{E}$ & W & $\mathrm{E}$ & W & W & $\mathrm{E}$ & W & $\mathrm{E}$ & $\mathrm{E}$ & 13 \\
\hline $27 / 28$ & $\bar{W}$ & W & $\bar{W}$ & $\mathrm{E}$ & $\mathrm{E}$ & W & $\mathrm{E}$ & W & W & $\mathrm{E}$ & W & $\bar{W}$ & $\mathrm{E}$ & 13 \\
\hline 29 & $\mathrm{E}$ & & $\mathrm{E}$ & $\mathrm{E}$ & $\mathrm{E}$ & W & $\mathrm{E}$ & $\mathrm{E}$ & & $\bar{W}$ & & W & $\mathrm{E}$ & 10 \\
\hline $30-33$ & $\mathrm{E}$ & & & $\mathrm{E}$ & $\mathrm{E}$ & W & $\mathrm{E}$ & $\mathrm{E}$ & & W & & W & $\mathrm{E}$ & 9 \\
\hline $34 / 35$ & & & & $\mathrm{E}$ & $\mathrm{E}$ & W & $\mathrm{E}$ & $\mathrm{E}$ & & W & & W & $\mathrm{E}$ & 8 \\
\hline Total & 10 & 8 & 9 & 12 & 12 & 12 & 12 & 12 & 8 & 11 & 5 & 12 & 11 & 134 \\
\hline
\end{tabular}

Table 8 Country/sector combinations included in the sample. E's are included in the employment oriented group, W's in the wage oriented group. 